\title{
New or little-known Pericalina and Cymindidina (Coleoptera: Carabidae: Lebiini) from the Oriental region
}

\author{
Новые и малоизвестные Pericalina и Cymindidina \\ (Coleoptera: Carabidae: Lebiini) из Ориентальной области
}

\author{
D.N. Fedorenko \\ A.H. Федоренко
}

\begin{abstract}
A.N. Severtsov Institute of ecology and evolution, Leninsky pr. 33, Moscow 119071 Russia. E-mail: dmitri-fedorenko@yandex.ru Институт проблем экологии и эволюции им. А.Н. Северцова, Российская Академия Наук, Ленинский пр-т, Москва 119071 Россия.
\end{abstract}

KEY WORDS: Coleoptera, Carabidae, Amphimenes, Amphimenoides, Gnopherus, Morphaeus, Pseudosinurus, Taridius, new species, new synonym, new combination, new record, Vietnam, Oriental region.

КЛЮЧЕВЫЕ СЛОВА: Coleoptera, Carabidae, Amphimenes, Amphimenoides, Gnopherus, Morphaeus, Pseudosinurus, Taridius, новый вид, новый синоним, новая находка, Вьетнам, Ориентальная область.

ABSTRACT. Four new ground-beetle species, $A m$ phimenes guttatus sp.n., A. planipennis sp.n., A. micros sp.n., and Taridius marginipennis sp.n., are described from Vietnam. The following nomenclative changes are made: Amphimenes Bates, $1873=$ Pseudosinurus Kirschenhofer, 1999, syn.n.; Pseudosinurus brunneus = Amphimenes brunneus (Kirschenhofer, 1999), comb.n.; A. medius Fedorenko, $2010=A$. minutus Fedorenko, 2010, syn.n.?; Gnopherus Andrewes, $1940=$ Amphimenoides Kirschehofer 1999, syn.n.; Amphimenoides maculatus = Gnopherus maculatus (Kirschehofer, 1999), comb.n.; Taridius Chaudoir, 1875 = Morphaeus Kirschenhofer, 1999, syn.n.; Taridius niger Andrewes, 1935 = Morphaeus corosus Kirschenhofer, 1999, syn.n. A refined identification key to species of Amphimenes is proposed. New records of some representatives of the genera Amphimenes and Taridius are discussed.

РЕЗЮМЕ. Из Вьетнама описаны 4 новых вида жужелиц: Amphimenes guttatus sp.n., A. planipennis Fedorenko, sp.n., A. micros sp.n. и Taridius marginipennis sp.n. Произведены следующие номенклатурные изменения: Amphimenes Bates, 1873 = Pseudosinurus Kirschenhofer, 1999, syn.n.; Pseudosinurus brunneus = Amphimenes brunneus (Kirschenhofer, 1999), comb.n.; A. medius Fedorenko, $2010=A$. minutus Fedorenko, 2010, syn.n.?; Gnopherus Andrewes, 1940 = Amphimenoides Kirschehofer 1999, syn.n.; Amphimenoides maculatus = Gnopherus maculatus (Kirschehofer, 1999), comb.n.; Taridius Chaudoir, 1875 = Morphaeus Kirschenhofer, 1999, syn.n.; Taridius niger Andrewes, 1935 = Morphaeus corosus Kirschenhofer, 1999, syn.n. Предложена новая таблица для определения Amphimenes. Обсуждаются новые находки нескольких видов Amphimenes и Taridius.

\section{Introduction}

The Oriental region supports a rich fauna of Lebiini, which is also true of Indochina including Vietnam. Many representatives of this fauna still remain poorly studied, among them the genera Amphimenes Bates, 1873, Pericalina, and Taridius Chaudoir, 1875, Cymindidina. Both have been reviewed quite recently, with several species described and keys to species provided [Fedorenko, 2010, 2012].

In this paper, four new species of the two genera are described based on fresh material from Vietnam while some others provided with new data, mostly new records. Furthermore, Amphimenes brunneus (Kirschenhofer, 1999), comb.n., and Gnopherus maculatus (Kirschehofer, 1999), comb.n., are re-described here, with new synonymy established and the key to species of $\mathrm{Am}$ phimenes [Fedorenko, 2010] refined.

The material has been collected during several expeditions to montane regions in Vietnam sponsored by the Joint Russia-Vietnam Tropical Center. Holotypes of the new species are deposited in the Zoological Museum of the Moscow State University (ZMMU), paratypes in the author's synoptic collection at A.N. Severtsov Institute of Ecology \& Evolution, Russian Academy of Sciences, Moscow (SIEE) and Zoological Institute, Russian Academy of Sciences, St. Petersburg (ZISP). The holotypes of the species described by Kirschehofer [1999] are deposited in the Hungarian Natural History Museum, Budapest (HNHM).

Each type specimen of the new species is supplied with a red typewritten label: 'HOLOTYPE (or PARATYPE) / Genus / species sp. n. / D. Fedorenko des. 2014'. Slash means a new line on a type or data label.

The following parameters were analyzed:

$\mathrm{BL}$ - maximum body length measured between apices of closed mandibles and apex of elytra; DN — maximum distance between base of elytron and discal pore $\mathrm{N}=1,2,3$; 
EL - maximum length of elytron; EW - maximum width of elytra; HW - width of head across eyes; PL length of pronotum along median line; PW - maximum width of pronotum. Means are given in round brackets, with the number of specimens measured (n) indicated for the first ratio in the description.

\section{Results}

Amphimenes Bates, 1873

Bates, $1873: 322$, type species A. piceolus Bates, 1873, by monotypy; Jedlička, 1963: 366; Habu, 1964: 472; 1967: 113; 1982: 90; Fedorenko, 2010: 18. — Pseudosinurus Kirschenhofer, 1999: 74 , syn.n.

\section{Amphimenes guttatus Fedorenko, sp.n.}

Figs 1, 5-6.

MATERIAL. Holotype $\sigma^{7}$ (ZMMU) and paratypes (ZISP, ZMMU, SIEE) $90^{7} \sigma^{7}, 8$ Oᄋ labelled: 'N-Vietnam, $25 \mathrm{~km} \mathrm{E}$ of / Hai Phong, Cat Ba is[land]., / Natn. Park, $\sim 10 \mathrm{~km} \mathrm{~N}$ of / Cat Ba City, $20^{\circ} 47^{\prime} 56^{\prime \prime} \mathrm{N} / 106^{\circ} 59^{\prime} 47^{\prime \prime}$ E 17. / D. Fedorenko leg. X.2011'.
DESCRIPTION. Habitus as in Fig. 1, BL 5.9-7.2 $\mathrm{mm}$. Black above, reddish beneath, sometimes with head and pronotum brown black; legs, antennae, mouthparts, anterior half to three fourths of clypeus, reflexed lateral margins of pronotum and elytra, and two large spots on each elytron reddish yellow; anterior spot rounded, slightly oblique towards suture, on intervals 3 to 7 , extending from slightly in front of $\mathrm{d} 1$ (anterior discal pore) to $2 / 3$ distance between $\mathrm{d} 1$ and $\mathrm{d} 2$; posterior spot elliptic, on intervals 1 to 4 or 5 , from midway between $\mathrm{d} 2$ and $\mathrm{d} 3$ to just in front of $\mathrm{d} 3$. Head and pronotum dull from granulate isodiametric microsculpture; elytra shining, with a well-developed cross-striated sculpture and superficial yet distinct microsculpture consisting of narrow transverse meshes.

Head typical for the rugulipennis-group [Fedorenko, 2010], with eyes large and almost hemispherical.

Pronotum transverse, $1.43-1.52(1.48, \mathrm{n}=6)$ times as wide as long, 1.49-1.65 (1.56) times as wide as head, broadest at anterolateral seta, with base wider than apex. Sides evenly rounded in apical two thirds, subsinuate to nearly straight before base; explanate lateral margin slightly reflexed throughout, increasingly widening basad, from narrow at apical angles to very wide basally. Base gently trilobed, with median lobe
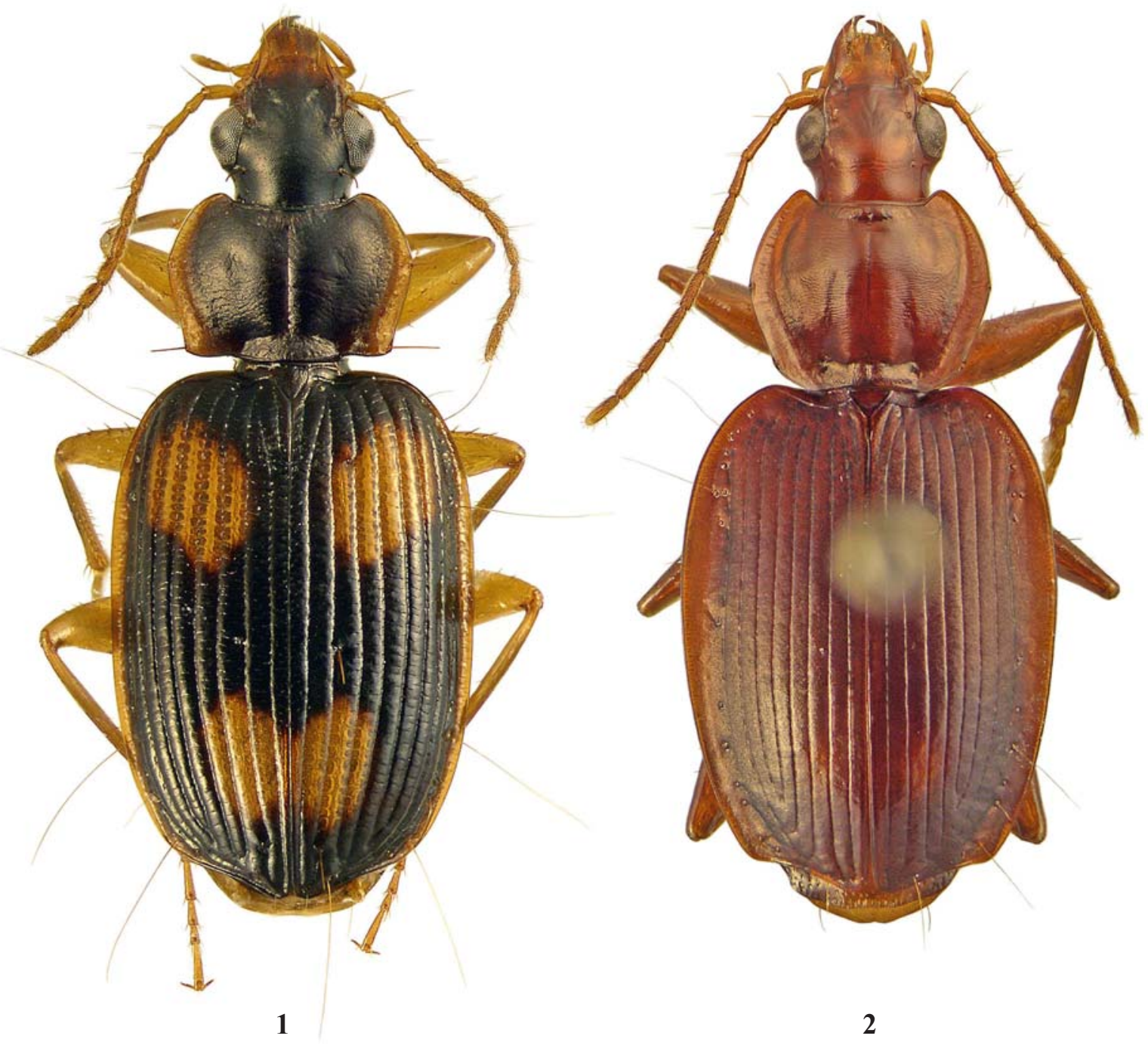

Figs 1-2. Dorsal habitus: 1 - Amphimenes guttatus sp.n.; 2 - Gnopherus maculatus.

Рис. 1-2. Габитус сверху: 1 - Amphimenes guttatus sp.n.; 2 - Gnopherus maculatus. 
broader than lateral lobes and slightly surpassing them; apex evenly deeply and concave. Basal angles obtuse and blunt, apical ones porrect, blunted at tips. Disc moderately convex, often flattened behind, slightly transversely rugulose throughout or at sides only. Median line deep, not quite reaching apical bead while missing behind basal transverse impression; this impression slightly angulate (angle directed forward), ill-defined to fairly deep. Basal foveae rather deep, shallow anteriorly, each at bottom with a small impression (in form of a pit or very short line oblique posterobasad) just in front of meeting point of base and its lateral part; an oblique convex fold or callosity often present between this impression and reflexed lateral margin. Paramedian foveae deep to (mostly) very shallow or missing, situated 1/3-2/5 from apex, equidistant from median line and lateral edge. Apical bead entire yet very narrow, basal bead interrupted in the middle.

Elytra subquadrate, 1.43-1.46 (1.45) times as long as wide, 1.43-1.54 (1.48) times as wide as pronotum, broadest at middle, almost parallel-sided in middle third, with base short, humeri and posterolateral angles rounded; apical truncature oblique, with only a trace of sinuation; apices blunt. Striae deep, crenulate, intervals convex, flat in the middle of disc. Discal setigerous pores three, D1/EL 0.14-0.15 (0.15), D2/EL 0.46-0.49 (0.48), D3/EL 0.89-0.90 (0.90). Macropterous.
Metepisternum long, ca. 1.4 times as long at outer margin as wide at anterior margin.

Last tarsomere with two pairs of ventral setae.

Male: profemur ventrally a third from base with a conspicuous pointed tubercle, mesotrochanter with a small pointed tubercle, nearly denticle; mesotibia in apical half with four tubercles along inner margin.

Penis (Figs 5-6): strongly asymmetric, swollen on left side a third from apex, with a wide, long and sharp longitudinal carina on right dorsolateral side between apical lamella and this swell.

DIAGNOSIS. This species surely belongs to the rugulipennis-group, its three species being very similar in appearance, color pattern first. A. guttatus sp.n. is larger than $A$. maculatus Fedorenko, 2010 while generally smaller than $A$. rugulipennis (Bates, 1892). The elytral microsculpture is transversely lined in A. rugulipennis vs. transversely reticulated in the other two species. In A. guttatus, the head and pronotum are less coarsely microsculptured, meshes being isodiametric rather than granulate, the pronotum clearly flatter, with the median line shallower, still so behind, and the reflexed lateral margin wider. The inner two or three elytral intervals slightly flatter on disc. The labrum and a greater part of clypeus constantly pale (vs. infuscate). The ventral tubercle
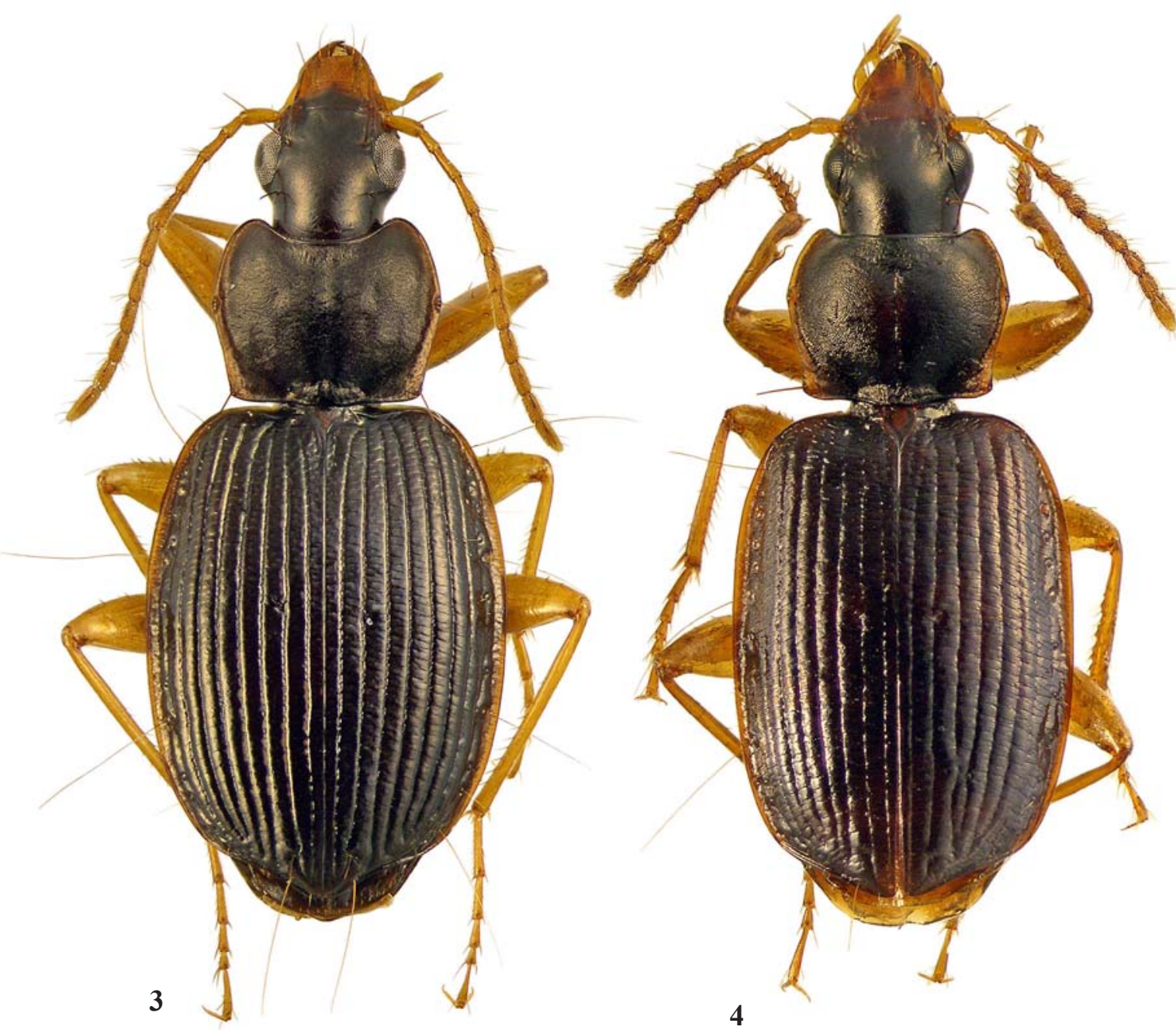

Figs 3-4. Amphimenes, dorsal habitus: $3-$ A. planipennis sp.n.; $4-$ A. micros sp.n.

Рис. 3-4. Amphimenes, габитус, сверху: $3-$ A. planipennis sp.n.; $4-$ A. micros sp.n. 


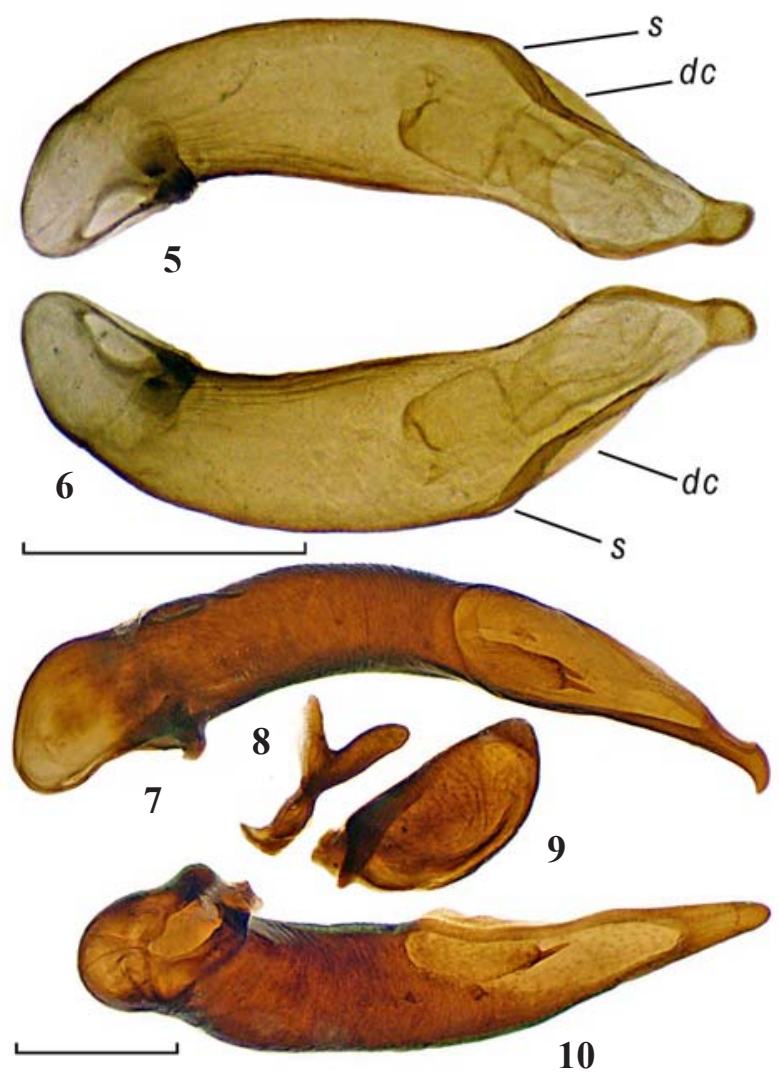

Figs 5-10. Aedeagus: 5-6 - Amphimenes guttatus sp.n.; 7 10 - Gnopherus maculatus; 5-7, 10 - penis; 8 - right paramere; 9 - left paramere; 5 - left ventrolateral view; 6 - right dorsolateral view; 7 - left lateral view; 10 - ventral view; $d c$ - dorsal carina; $s$ - swell. Scale bar $0.5 \mathrm{~mm}$.

Рис. 5-10. Эдеагус: : 5-6 - Amphimenes guttatus sp.n.; 7-10Gnopherus maculatus; ; 5-7, 10 - пенис; 8- правая парамера; 9 левая парамера; 5 - слева и снизу; 6 - справа и сверху; 7 - слева; 10 - снизу; $d c$ - дорзальный киль; $s$ - вздутие. Масштаб 0.5 мм.

on male profemur is conspicuous vs. small and blunt in $A$. rugulipennis or missing in A. maculatus. Finally, each of the three species is defined by a particular spotted pale pattern on the elytra. While occupying intervals 3 to 7 (A. guttatus and $A$. maculatus) or 3 to 8 (A. rugulipennis), the anterior spot becomes stepwise longer from $A$. rugulipennis to $A$. maculatus. Usually it extends backwards to the midway between $\mathrm{d} 1$ and $\mathrm{d} 2$ in A. rugulipennis, $2 / 3$ distance between $\mathrm{d} 1$ and $\mathrm{d} 2$ in $A$. guttatus sp.n. and reaching $\mathrm{d} 2$ in $A$. maculatus. Besides, the penis is differently shaped and structured in these species, being much less asymmetrical and devoid of any swell or carina in $A$. rugulipennis and $A$. maculatus.

DISTRIBUTION. North Vietnam and probably also central Vietnam.

NAME. Refers to the spotted color pattern on the elytra.

HABITATS AND HABITS. All specimens have been collected under exfoliated bark pieces of living trees in a broadleaf monsoon forest.

COMMENTS. The record of this species in central Vietnam is based on a single female(Prov. Quang Binh, Minh Hoa [= Quy Đat] distr., env. Yen Hop, 2-8.IV.1999, leg. S. Kruskop, collection of the Moscow Pedagogical State University, MPSU) which is different from the type series in the following points. The pronotum is wider, with lateral margins more reflexed, the elytral discal pore $\mathrm{d} 2$ situated just behind middle, the anterior spot on the elytra smaller while the posterior ones combined form a U-shaped figure. It follows that this specimen may belong to a separate species, therefore the record discussed needs confirmation.

\section{Amphimenes brunneus (Kirschenhofer, 1999), comb.n.}

Kirschenhofer, 1999: 74 (Pseudosinurus; Dang Khao, Vietnam). MATERIAL. Holotype + (HNHM): 'VIETNAM, Dang Khao / 29.XI.1971. / No.163 / leg. Gy.TOPÁL', red 'Holotypus, Pseudosinurus gen.n. / brunneus sp.n. / det. Kirschenhofer 1999'.

REDESCRIPTION. Stout, BL $5.7 \mathrm{~mm}$. Black, legs, antennae and mouthparts reddish-yellow, labrum, anterior half of clypeus and explanate lateral margin of pronotum slightly translucent with reddish; reflexed lateral margin of elytra red. Head and pronotum dull from coarse isodiametric microsculpture. Elytra shiny, with a fine microsculpture consisting of slightly to rather strongly transverse meshes; cross-striated sculpture strongly reduced to sparse and shallow subtransverse hatches, almost punctures, hardly traceable in basal half only.

Head: eyes flattened, posterior supraorbital seta behind posterior margin of eye.

Pronotum cordate, 1.32 times as wide as long, 1.38 times as wide as head; base slightly wider than apex, gently trilobed, with lobes rounded and subequally wide, beaded only laterally; basal angles obtuse and blunt; apex evenly and rather deeply sinuate, narrowly beaded, apical angles prominent, blunted at tips. Sides distinctly sinuate before base, reflexed lateral margin gradually yet very gently broadening basad, very narrow anteriorly and only moderately wide in basal fourth. Disc convex with a pair of distinct paramedian foveae equidistant from apex, median line and lateral margin. Median line moderately deep, reaching apical bead and almost reaching base. Basal transverse impression moderately deep, invertedly Vshaped obtusangular. Basal foveae rather large, almost reaching middle, very shallow anteriorly, each with a fairly deep pit just before meeting point of base proper and its lateral part.

Elytra broadly oval, 1.38 times as long as wide, 1.67 times as wide as pronotum, broadest at middle, with posterolateral angles rounded, apical truncature oblique and very gently sinuate; apices blunt, forming obtuse to nearly right angle combined. Elytral striae deep, indistinctly crenulate at bottom; intervals convex. Discal setigerous pores two, D2/ EL 0.45, D3/EL 0.90. Apterous.

Last tarsomere with one pair of ventral setae.

DIAGNOSIS. Very near to A. kabakovi Fedorenko, 2010, but more slender, elytra longer, pronotum longer relative to head, sides of pronotum distinctly sinuate behind, and microsculpture coarse over head and entire pronotum.

DISTRIBUTION. Known from type locality only.

COMMENTS. Kirschenhofer [1999] following Jedlička [1963] wrongly believed that the genus Amphimenes Bates, 1873 had the edentate mentum. It is this misunderstanding that led him to erection of the monobasic genus Pseudosinurus. Because P. brunneus does belong to Amphimenes, Pseudosinurus Kirschenhofer, 1999 is a junior synonym of Amphimenes Bates, 1873.

\section{Amphimenes planipennis Fedorenko, sp.n.}

Figs 3, 11-13.

MATERIAL. Holotype $O^{7}$ (ZMMU): 'N-Vietnam, Phu Tho Prov[ince]. / 90 km W of Hanoi, / Xuan Son Natn. Park / $21^{\circ} 07^{\prime} 01^{\prime \prime}$ $\mathrm{N}, 104^{\circ} 56^{\prime} 39^{\prime \prime} \mathrm{E} / \mathrm{h}=400-700 \mathrm{~m} \mathrm{6}$-15.VI. / D. Fedorenko leg. 2014'. Paratypes (ZISP, ZMMU, SIEE): $14 \bigcirc^{7} \sigma^{7}, 9$ 우, same data; 9 , same data, but $21^{\circ} 07^{\prime} 52^{\prime \prime} \mathrm{N}, 104^{\circ} 57^{\prime} 07^{\prime \prime} \mathrm{E} / \mathrm{h}=400-470 \mathrm{~m} ; 3 \mathrm{O}^{\prime} \mathrm{o}^{\prime \prime}$, ㅇ, same data, but $21^{\circ} 06^{\prime} 39^{\prime \prime} \mathrm{N}, 104^{\circ} 57^{\prime} 25^{\prime \prime} \mathrm{E} / \mathrm{h}=400 \mathrm{~m}$. 
DESCRIPTION. Stout (Fig. 3), BL 5.3-6.2 mm. Black, head often brown black or dark brown, with anterior half of clypeus (sometimes entire clypeus and frons just behind it) reddish; reflexed lateral margins of pronotum and elytra translucent with dark red, legs, antennae, mouthparts and prosternal intercoxal process reddish yellow, venter otherwise brown black or dark brown. Head and pronotum dull from granulate isodiametric microsculpture, vertex and neck slightly shiny owing to a little more superficial microsculpture, elytra shiny and very slightly iridescent due to highly superficial, nearly obliterate microsculpture consisting of dense transverse lines. Elytra with cross-striated sculpture fine yet conspicuous, weakening gradually apicad, almost obliterate just before apex only.

Head: eyes slightly flattened, genae moderately long, posterior supraorbital seta clearly behind posterior margin of eye. Antennae moderately long, surpassing base of pronotum by last two joints.

Pronotum subquadrate to subcordate, 1.33-1.41 (1.37, $\mathrm{n}=5)$ times as wide as long, $1.43-1.48(1.45)$ times as wide as head, broadest at anterolateral seta, with base gently and subequally trilobed, apex very deeply and evenly concave. Sides evenly rounded in apical two thirds to barely angulate at anterolateral seta and thence nearly straight on each side of it, mostly clearly sinuate, sometimes almost straight, before base. Basal angles obtuse and blunt, apical angles porrect, rounded at tips. Disc slightly convex; reflexed lateral margin broadening gradually basad, from narrow anteriorly to moderately wide in basal half. Median line moderately deep, reaching or not quite reaching base and apical bead; basal transverse impression well defined, angulate or convex forward; basal foveae very weak to almost indistinct, reduced to small pits just in front of meeting points of base and its lateral parts; paramedian foveae small, shallow, situated a third from apex, equidistant from median line and lateral edge.

Elytra broadly oval, 1.29-1.42 (1.36) times as long as wide, 1.58-1.72 (1.66) times as wide as pronotum, broadest at middle, with base narrow, transverse or very slightly oblique forward; shoulders widely rounded, posterolateral angles rounded, apical truncature very gently sinuate; apices blunt, forming obtuse to nearly right angle combined. Striae deep, almost indistinctly crenulate at bottom; intervals flat on disc, subconvex to convex along sides and before apex (rarely convex in apical half). Discal setigerous pores two, D2/EL $0.40-0.46(0.44), \mathrm{D} 3$ as for the genus, i.e., just before apex (means D3/EL 0.90-0.94). Apterous.

Metepisternum short, about as wide at anterior margin as long at outer margin.

Last tarsomere with one pair of ventral setae.

Male profemur and mesotrochanter without tubercles.

Penis (Figs 11-13): asymmetric a little, subequally wide except at base and at apex; apical lamella in ventral view parallel-sided, rounded at tip.

DIAGNOSIS. This species is similar and closest to $A$. kabakovi Fedorenko, 2010 and A. brunneus. It is distinguishable from both in a particular sculpture of the elytra: the intervals flat (vs. convex), the cross-striated sculpture welldeveloped (vs. rudimentary and traceable in basal half at best), the microsculpture transversely lined and almost obliterate (vs. fine yet distinct transverse meshes).

DISTRIBUTION. Known from type locality only.

NAME. Refers to the flat elytra with flat intervals.

HABITATS AND HABITS. All specimens of the type series have been taken by handing in a broadleaf monsoon forest. The adults occur predominantly on lower surface of fallen bark fragments around larger dead-woods.

\section{Amphimenes micros Fedorenko, sp.n. Figs 4, 14-16.}

MATERIAL. Holotype $\sigma^{7}$ (ZMMU): 'Vietnam, Dak Lak Prov. / Chu Yang Sin Natn. Park, / $12^{\circ} 22^{\prime} 40^{\prime \prime} \mathrm{N} 108^{\circ} 21^{\prime} 11^{\prime \prime} \mathrm{E} / 1.5 \mathrm{~km} \mathrm{~W}$ [of] Chu Pan Phan Mt / h=1650 m, 30.III-11. / D. Fedorenko leg. IV.2012,

DESCRIPTION. As for A. planipennis sp.n. except as follows: Body (Fig. 4) slender and small, BL $4.7 \mathrm{~mm}$. Forehead and pronotum dull from granulate isodiametric microsculpture, elytra shiny, with microsculpture consisting of narrow transverse meshes, combined with a well-developed cross-striated sculpture.

Eyes small and rather flat, genae imperceptible as being very smoothly extended into neck. Antennae short, not quite reaching base of pronotum; middle joints slightly, about a fifth, longer than wide.

Pronotum subcordate, 1.29 times as wide as long, 1.47 times as wide as head, broadest at anterolateral seta. Sides evenly rounded in apical three fourths and gently sinuate in front of basal angles. Base gently trilobed, with lateral parts narrower than and slightly in advance of base proper; apex gently concave. Apical angles porrect, with tips blunted, basal angles obtuse. Disc convex, reflexed lateral margin very narrow, hardly wider in basal half, moderately wide at basal angles only. Median line deep, deeper basally, obliterate anteriorly and behind basal transverse impression. This impression transverse and rather deep; basal foveae as small pits just in front of meeting points of base and its lateral parts; paramedian foveae missing. Basal bead obliterate in the middle, apical bead obsolete medially.

Elytra subrectangular, 1.40 times as long as wide, 1.54 times as wide as pronotum; sides slightly rounded; apical truncature indistinctly sinuate; apices blunt. Elytral striae moderately deep, crenulate; intervals very slightly convex. Discal setigerous pores two, D2/EL 0.44, D3/EL 0.92. Macropterous.

Metepisternum fairly long, slightly longer at outer margin than wide at anterior margin.

Last tarsomere with one pair of ventral setae.

Male mesotrochanter with a minute yet distinct tubercle.

Penis (Figs 14-16): slightly asymmetric; apical lamella in ventral view fairly wide, with tip rounded and slightly curved upwards.

DIAGNOSIS. The unspotted body, combined with only two discal setigerous pores, $\mathrm{d} 2$ situated just before middle and $\mathrm{d} 3$, present on the elytra, defines this species as a member of the planicollis-group. But, unlike the other species of this group, A. micros sp.n. is a very small and winged insect with very short antennae. Besides, it shares the small size and a particular color pattern of the body, as well as the short antennae and the apical pronotal bead obliterated medially, with A. rufipes Fedorenko, 2010 only (A. rufipes has the antennae still shorter, with at least joints 6 to 9 as wide as long). This latter species is otherwise very peculiar in the genus, showing as it does apterous condition, the elytra broadest before apex, with cross-striated sculpture missing and microsculpture isodiametric.

DISTRIBUTION. Known from type locality only.

NAME. Refers to the small-sized body.

HABITATS AND HABITS. The holotype has been taken together with several specimens of Amphimenes medius Fedorenko, 2010 in a broadleaf monsoon forest, all under small tree remains on the soil surface.

COMMENTS. The cross-striated sculpture on the elytra tends to be strongly reduced in many members of the planicollis-group and totally reduced in A.rufipes. This fact, coupled with great similarity between $A$. rufipes and $A$. 

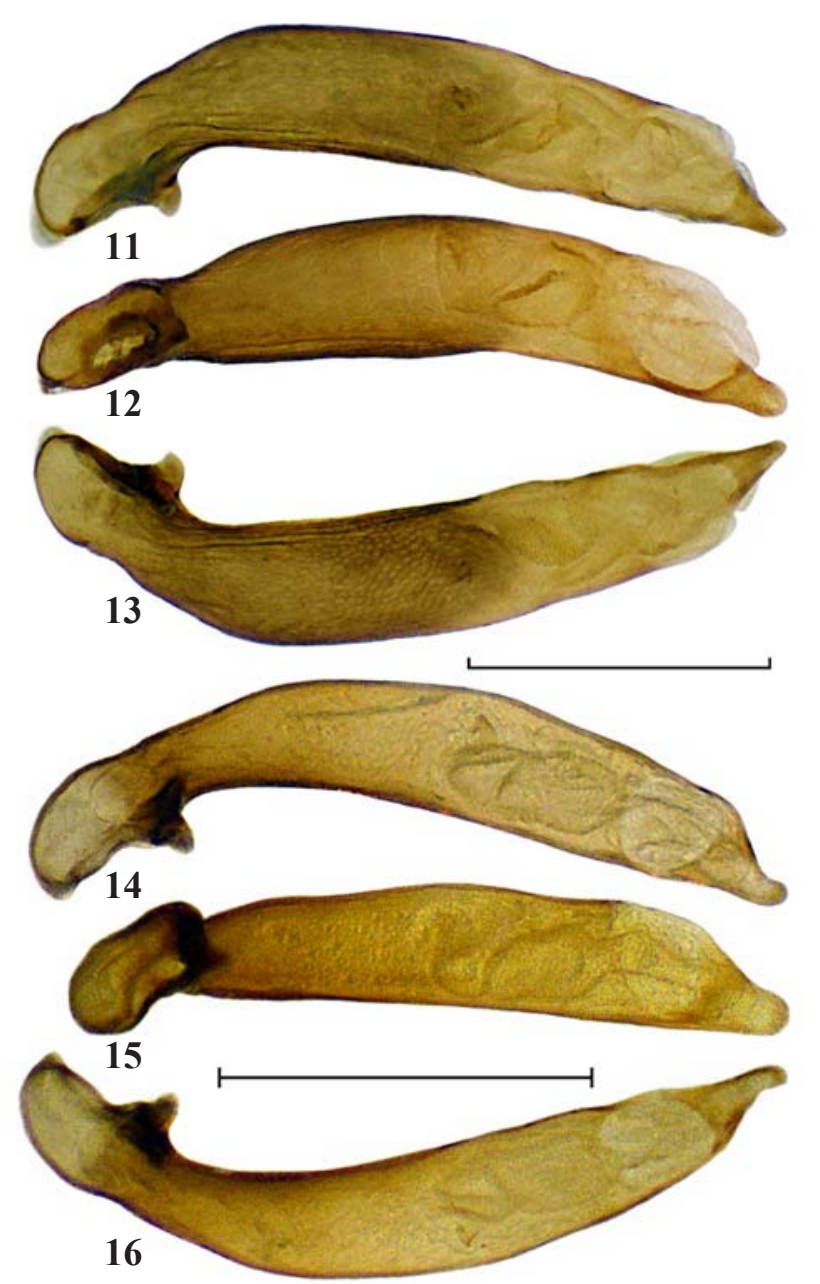

Figs 11-16. Amphimenes, penis: 11-13 - A. planipennis sp.n.; 14-16 - A. micros sp.n.; 12, 15 - ventral view; 11, 14 - left view; 13,16 - right view. Scale bar $0.5 \mathrm{~mm}$.

Рис. 11-16. Amphimenes, пенис: 11-13 - A. planipennis sp.n.; 14-16 - A. micros sp.n.; 12, 15 - снизу; 11, 14 - слева; 13, 16 - справа. Масштаб 0.5 мм.

micros sp.n., implies close affinity of both. Hence, I deem it expedient to include $A$. micros sp.n. in the rufipes-group first and downgrade this group to a subgroup of the planicollisgroup after. In having the discal seta $\mathrm{d} 2$ situated before the middle of the elytra $A$. rufipes and $A$. micros sp.n. are followed by $A$. brunneus, $A$. kabakovi, A . planipennis, and $A$. nitidus which all are distinctive in the body larger, the antennae longer, the elytra and the pronotum broader, and the pronotal apical bead entire. Hence, the brunneus-subgroup nov. is proposed here for the latter four species, thus leaving the remaining two species of the group, A planicollis $\mathrm{Fe}-$ dorenko, 2010 and A. reflexicollis Fedorenko, 2010 in the nominate subgroup; this subgroup is defined by $\mathrm{d} 2$ situated behind the middle of the elytra.

\section{Amphimenes medius Fedorenko, 2010}

Fedorenko, 2010: 34 (Bi Doup - Nui Ba Nat. Res., S-Vietnam). - minutus Fedorenko, 2010: 36 (Bi Doup Mt, S-Vietnam), syn.n.?

NEW RECORDS. Vietnam, Dak Lak Prov., Chu Yang Sin Natn. Park, $12^{\circ} 22^{\prime} 40^{\prime \prime} \mathrm{N} / 108^{\circ} 21^{\prime} 11^{\prime \prime} \mathrm{E}, \sim 1.5 \mathrm{~km}$ W of Chu Pan Phan $\mathrm{Mt}, \mathrm{h}=1400-1650 \mathrm{~m}, 30 . \mathrm{III}-11 . \mathrm{IV} .2012$ and 19.III-2.IV.2013 (D.
Fedorenko), $39 \mathrm{O}^{\top} \mathrm{O}^{\top}, 19$ 옹 same data, but $12^{\circ} 24^{\prime} 32^{\prime \prime} \mathrm{N} / 108^{\circ} 23^{\prime} 17^{\prime \prime} \mathrm{E}$, $\sim 3 \mathrm{~km}$ W of Chu Yang Sin Mt, h=1500-1600 m, 15-30.V.2014, o', 4 우오.

DISTRIBUTION. The species is known from several localities within the Dalat plateau, Lam Dong and Dak Lak provinces, southern Vietnam.

COMMENTS. A. minutus has been described from three females different from $A$. medius in nothing else but the combination of a slenderer body, narrower pronotum, very small and flat eyes. Taken separately each, these features have nevertheless been observed in individual specimens of A. medius from the localities listed above. In these specimens, mostly females, either the eyes are rather flat or the pronotum fairly narrow, implying that $A$. minutus could have only been a form, perhaps an ecological one, of A. medius.

\section{Amphimenes giganteus Fedorenko, 2010}

Fedorenko, 2010: 32 (Bi Doup Mt, S-Vietnam).

NEW RECORDS. $4 \sigma^{7} \sigma^{7}$ and 10 of, same locality as the first one of $A$. medius.

DISTRIBUTION. As for A. medius.

CORRECTED COUPLETS OF THE KEY TO SPECIES OF AMPHIMENES [FEDORENKO, 2010]:

3(6) Elytra dark, with a pale spotted pattern (Figs 4, 5). Body appendages yellow, contrastingly paler than ground color of body dorsum. Discal setigerous pores on elytra three: $\mathrm{d} 1$ (near base, $\mathrm{D} 1 / \mathrm{EL}=\mathrm{ca} 0.15)+\mathrm{d} 2$ (at middle $)+\mathrm{d} 3$. Macropterous.

4(5) Elytral microsculpture consisting of fine and very dense transverse lines not forming distinct meshes. Elytral pale spots smaller; anterior spot on intervals 3-8 just behind humerus while not surpassing midway between $\mathrm{d} 1$ and $\mathrm{d} 2$ behind; posterior spot not extended forward beyond the midway between $\mathrm{d} 2$ and $\mathrm{d} 3$. Profemur at base with small and blunt ventral tubercle in male. Larger, BL 6.3-7.7 mm A. rugulipennis (Bates, 1892)

5(4) Elytral microsculpture consisting of strongly transverse yet distinct meshes; elytral pale spots larger, anterior one on intervals 3 to 7 clearly behind humerus and surpassing midway between $\mathrm{d} 1$ and $\mathrm{d} 2$ behind; posterior spot extended forward beyond the midway between D2 and D3. Profemur without or with a ventral tubercle in male. Body generally smaller, BL 5.3-7.2 mm.

a(b) Smaller, BL 5.3-5.7 mm. Anterior pale spot on elytra reaching or almost reaching $\mathrm{d} 2$. Clypeus and labrum infuscate. Elytra shorter, 1.32-1.42 (mean 1.35) times as long as wide. Pronotum convex on disc, with explanate lateral margins moderately wide. Microsculpture on head and pronotum very coarse, granulate. Profemur with no tubercle in male ............ A. maculatus Fedorenko, 2010

b(a) Larger, BL 5.9-7.2 mm. Anterior pale spot on elytra extended backwardly to about $2 / 3$ distance between $\mathrm{d} 1$ and d2. Labrum and greater part of clypeus pale. Elytra longer, 1.43-1.46 (mean 1.45) times as long as wide. Pronotum rather flat, with explanate lateral margins wider. Microsculpture on head and pronotum slightly more superficial, isodiametric rather than granulate. Profemur with a conspicuous sharp tubercle in male ........ 2. A. guttatus sp.n.

6(3) Elytra monochromous dark, body appendages mostly darker than above. Discal setigerous pores either two, $\mathrm{d} 1+\mathrm{d} 3$ or $\mathrm{d} 2+\mathrm{d} 3$, or $\mathrm{d} 2$ situated far behind middle ( $\mathrm{D} 2 / \mathrm{EL}=0.61-0.76$ ).

$25(28) \mathrm{d} 2$ situated behind the middle (D2/EL $=0.55-0.67$ ). Elytra conspicuously cross-striated throughout. 
$28(25)$ d 2 situated before middle (D2/EL $=0.41-0.44)$.

29(30) Elytra with microsculpture forming distinct transverse meshes; restricted to base only or hardly traceable in basal half.

a (b) Body winged and very small, BL $4.7 \mathrm{~mm}$. Apical bead of pronotum obsolete medially. Entire elytra with welldeveloped cross-striated sculpture. Elytra and especially pronotum narrower, latter less than a third wider than long A. planipennis sp.n.

$\mathrm{b}$ (a) Body wingless and larger, over $5.3 \mathrm{~mm}$ in length. Apical bead of pronotum entire. Elytra and pronotum broader, latter more than a third wider than long.

c (d) Head and entire pronotum dull from granulate microsculpture. Elytral microsculpture consisting of transverse, narrow to rather wide, meshes; cross-striated sculpture hardly traceable in basal half. Sides of pronotum sinuate behind. BL $5.7 \mathrm{~mm}$.. A. brunneus (Kirschenhofer, 1999)

$\mathrm{d}$ (c) Head and pronotum shining due to microsculpture more superficial, isodiametric rather than granulate, and still more superficial at middle of pronotum. Elytral microsculpture strongly transverse; cross-striated sculpture restricted to base. Sides of pronotum indistinctly sinuate behind. BL $6.3 \mathrm{~mm}$........ A. kabakovi Fedorenko, 2010

30(29) Elytral microsculpture transversely lined, not forming distinct meshes.

e(f) Cross-striated sculpture very superficial and restricted to base of elytra. Pronotum broader, slightly more than a half wider than long and so much wider than head. Body larger, BL $7.2 \mathrm{~mm}$.............. A. nitidus Fedorenko, 2010

f(e) Elytra with cross-striated sculpture distinct throughout or obliterated at apex only. Pronotum two fifths wider than long at best and less than a half wider than head. Body smaller, BL 5.3-6.2 $\mathrm{mm}$ A. planipennis sp.n.

\section{Gnopherus Andrewes, 1940}

Andrewes, 1940: 536, replacement name. - Gnophodes Andrewes, 1923: 244 (non Doubleday, 1839), type species G. pearsoni Andrewes, 1923, by original designation. - Amphimenoides Kirschehofer, 1999: 74, syn.n., type species A. maculatus Kirschehofer, 1999, by original designation.

Gnopherus maculatus (Kirschehofer, 1999), comb.n. Figs 2, 7-10

MATERIAL. Holotype + (HNHM): 'CEYLON, C Prov. / Nuwara Eliya / 23-24.VI.1968', 'no.CMB-C.4. / leg.Dr.J.Balogh', red 'Holotypus / Amphimenoides gen.n. / maculatus sp.n. / det. Kirschenhofer 1999".

ADDITIONAL MATERIAL. $1 \sigma^{7}$ (ZISP): 'Peradenyia, Ceylon, 19075 IV, O. John.'

REDESCRIPTION. Habitus as in Fig. 2, BL 9.3-9.5 mm. Red, elytra dark brown with explanate lateral margins red, each elytron with a vague preapical red spot on intervals 3 and 4 or 3 to 5 a fourth from apex. Clypeus and labrum yellow, palps reddish-yellow. Tibiae with a dark stripe along outer margin. Head and pronotum rather shiny, with a fairly sharp microsculpture, isodiametric on head while consisting of small and narrow transverse meshes on pronotum; elytra dull from very coarse, almost granulate, microsculpture consisting of isodiametric to very slightly longitudinal meshes; this microsculpture becoming gradually weaker backwards in apical half, and still weaker towards sutural angle, thus leaving a subtriangular area tapering forward shiny, still more so at apex.

Head. Eyes moderately large and moderately prominent, much longer than genae, these short, smoothly extended into neck, posterior supraorbital seta a little behind the level of eye posterior margin; frons and vertex convex, without neck constriction; a shallow V-shaped impression behind frontoclypeal suture, followed by a short and shallow median stria; a trace of longitudinal carina between anterior and posterior supraocular setae each side. Labrum as long as wide, sides slightly converging forward, front angles rounded, a conspicuous emargination between them, four inner setae in advance of a pair of lateral, much stronger ones. Mandibles almost straight. Antennae long, surpassing pronotal base by about last two joints, pubescent from antennomere 5 onwards; a very distinct secondary pubescence present on antennomeres 3 and 4; antennomere 2 sparsely pubescent; lengths of antennomeres 1:2:3:4= 15:9:17:13, remaining antennomeres much longer than wide.

Pronotum subcordate, 1.28-1.29 times as wide as long, 1.57-1.60 times as wide as head, bisetose each side, broadest at middle; sides well rounded in anterior three fourths, with a trace of sinuation behind. Base slightly narrower than apex, straight, its sides strongly oblique forward and rounded; basal angles rounded off; apex deeply emarginate; apical angles projecting far, blunted at tips. Explanate lateral margin rather strongly reflexed, moderately wide in anterior fourth, thence broadening and subequally wide behind middle. Apical bead entire, basal bead hardly traceable at sides only. Subapical transverse impression indistinct, basal one moderately deep; basal foveae rather small, rounded, deep and smooth; median line fine and shallow; disc smooth.

Elytra ovate, 1.31-1.32 times as long as wide, 1.57-1.60 times as wide as pronotum, broadest clearly before middle, with sides rounded, more strongly so in basal half. Base straight, slightly oblique forward from peduncle to shoulder, with subbasal ridge very sharp, carinate, convex backwards. Humeral angle obtuse but very distinct, clearly in advance of subbasal ridge at its starting point near scutellum. Lateral margin widely explanate and a little reflexed in basal half, narrowed apicad. Apical truncature oblique and sinuate, its outer angle obtuse, rounded a little; apices rounded separately each. Striae impressed yet rather shallow, finely crenulate; parascutellar striole long; striae 1 and 2 adjoining slightly behind parascutellar pore situated close to subbasal ridge. Interval 3 with two small discal pores, $\mathrm{d} 2$ at middle and $\mathrm{d} 3$ equidistant from $\mathrm{d} 2$ and apex. Umbilical setae series subdivided into posthumeral (eight setae) and postmedian (seven setae) groups; setigerous pores 4-6 and 8 situated close to stria 8 , pore 6 equidistant from pores 5 and 8 , pore 7 situated in stria 9 slightly behind pore 6 . Stria 7 very shallow apically, with a single setigerous pore opposite interval 3 .

Metepisterna hardly (1.07 times) longer at outer margin than wide at anterior margin. Venter smooth. Abdominal sterna 4-6 with one pair of ambulatory setae, sternite 7 bisetose at apex in male while quadrisetose in female. Prothorax sparsely ciliate between coxae, metaventrite with dense and fairly long pubescence, venter otherwise glabrous.

Claws pectinate, with 6-8 teeth in metatarsi, smooth in apical third; tarsomere 5 with 3 pairs of ventral setae. Basal three protarsomeres dilated in male and supplied with adhesive vestiture beneath. Coxae, trochanters and femora along inner margins densely pubescent in hind two leg pairs; profemora with similar yet much shorter pubescence. Metacoxa with at least anterolateral seta.

Aedeagus (Figs 7-10): penis with apical orifice large, welldefined, shifted to the left side; apical lamella long, tapering and rounded at tip in ventral view, with a well-developed capitulum curved downwards in lateral view; internal sac with two close large spines and several minute ones hear and there.

DIAGNOSIS. This species is the second representative of the genus. It is a little smaller than $G$. pearsoni which is $9.5-10.5 \mathrm{~mm}$ in length and quite differently colored, i.e., with the elytra monochromous dark red while the head and prono- 
tum black, except for pale lateral margins of the pronotum. The pronotum of $G$. pearsoni is narrower besides, as long as wide, while almost three fourths wider than the head.

DISTRIBUTION. Sri Lanka.

COMMENTS. Gnopherus was described as a monobasic genus very peculiar within Pericalina due mainly to the elytral stria 9 reduced, combined with the reflexed lateral margin of the elytra very widely explanate. Apart from slight differences in size and color of the body, Amphimenoides maculatus fits well the description of Gnopherus, including the smallest details. Moreover, both $G$. pearsoni and $A$. maculatus originate from Sri Lanka, being not reported from the mainland Hindustan. Given these facts, I consider Amphimenoides as a junior subjective synonym of Gnopherus.

\section{Taridius Chaudoir, 1875}

Chaudoir, 1875: 7, type species T. opaculus Chaudoir, 1875, by monotypy; Andrewes, 1935: 204; Kirschenhofer, 2010: 20; Fedorenko, 2012: 68. - Perseus Kirschenhofer, 2003: 7, type species P. pahangensis Kirschenhofer, 2003, by original designation. Morphaeus Kirschenhofer, 1999: 73, syn.n., type species M. corosus Kirschenhofer, 1999, by original designation.

Taridius niger Andrewes, 1935

Andrewes, 1935: 205 (Madras, S-India), - corosus Kirschenhofer, 1999: 73 (Morphaeus; Kodaikanal, S-India), syn.n.

MATERIAL. Holotype O' (HNHM): 'INDIA, Tamil Nadu / Palni Hills / Kodaikanal, 2300 m / leg. Gy. Topál', 'singled / 10. IV. 1980.', red 'Holotypus, Morphaeus gen.n. / corosus sp.n. / det. Kirschenhofer 1999'.

COMMENTS. Morphaeus corosus was described as a new genus (and a new species) closest to Formosiella Jedlička, 1951 and thence a member of the lebiine subtribe Pericalina. My revision of the holotype of $M$. corosus has revealed conspecifity of this species with Taridius niger. The latter was described from several localities in Madras State, South India, among them Kodaikanal in Palni Hills, type locality of $M$. corosus.

The two species are quite conformable to each other, except for two smallest details as follows. According to the original description, $T$. niger is somewhat larger, $6-7.5 \mathrm{~mm}$ in length, with the pronotal microsculpture consisting of strongly transverse meshes. T. corosus is $5.4 \mathrm{~mm}$ in length $(5.1 \mathrm{~mm}$, as specified in the original description), with slight traces of strongly transverse microsculpture on the pronotal disc.
17

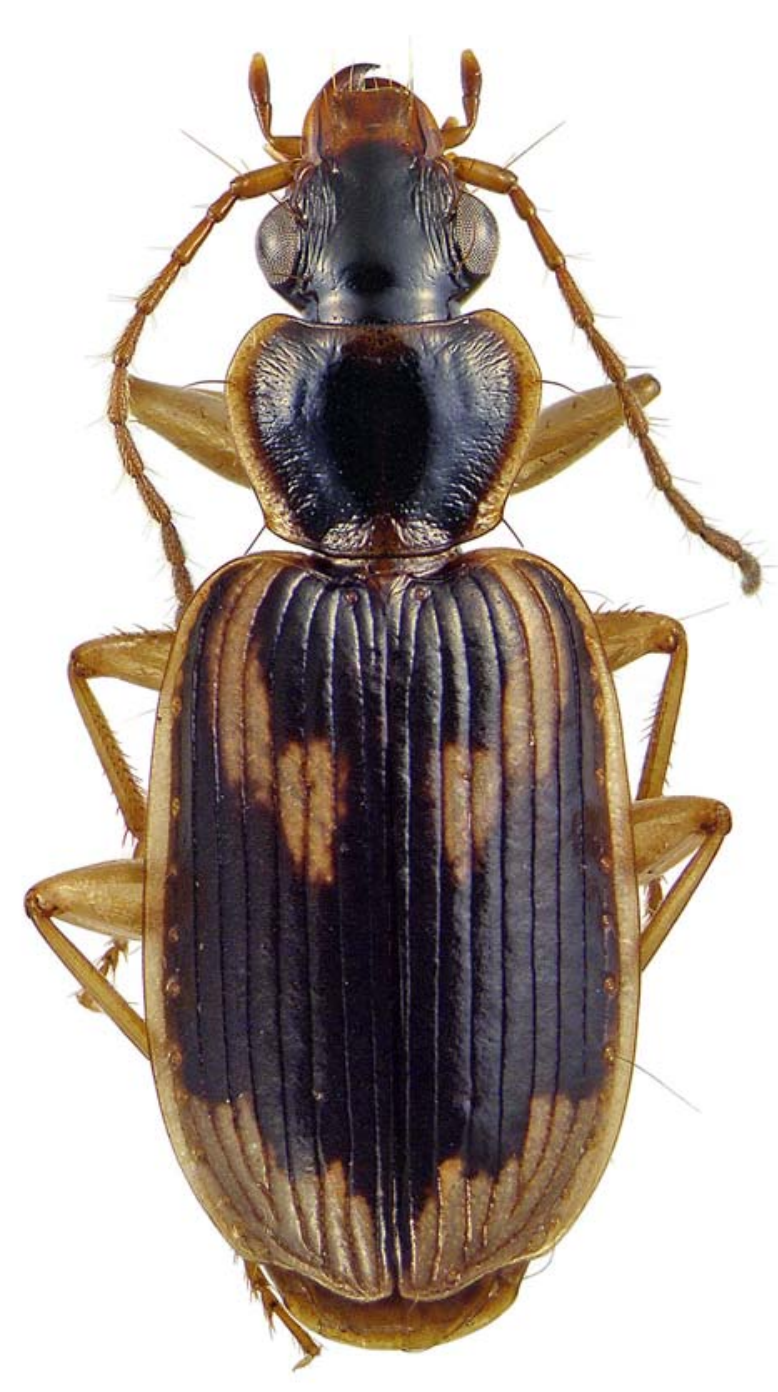

Figs 17-18. Taridius, dorsal habitus: 107 - T. ornatus, a specimen from Chu Yang Sin; 18 - T. marginipennis sp.n.

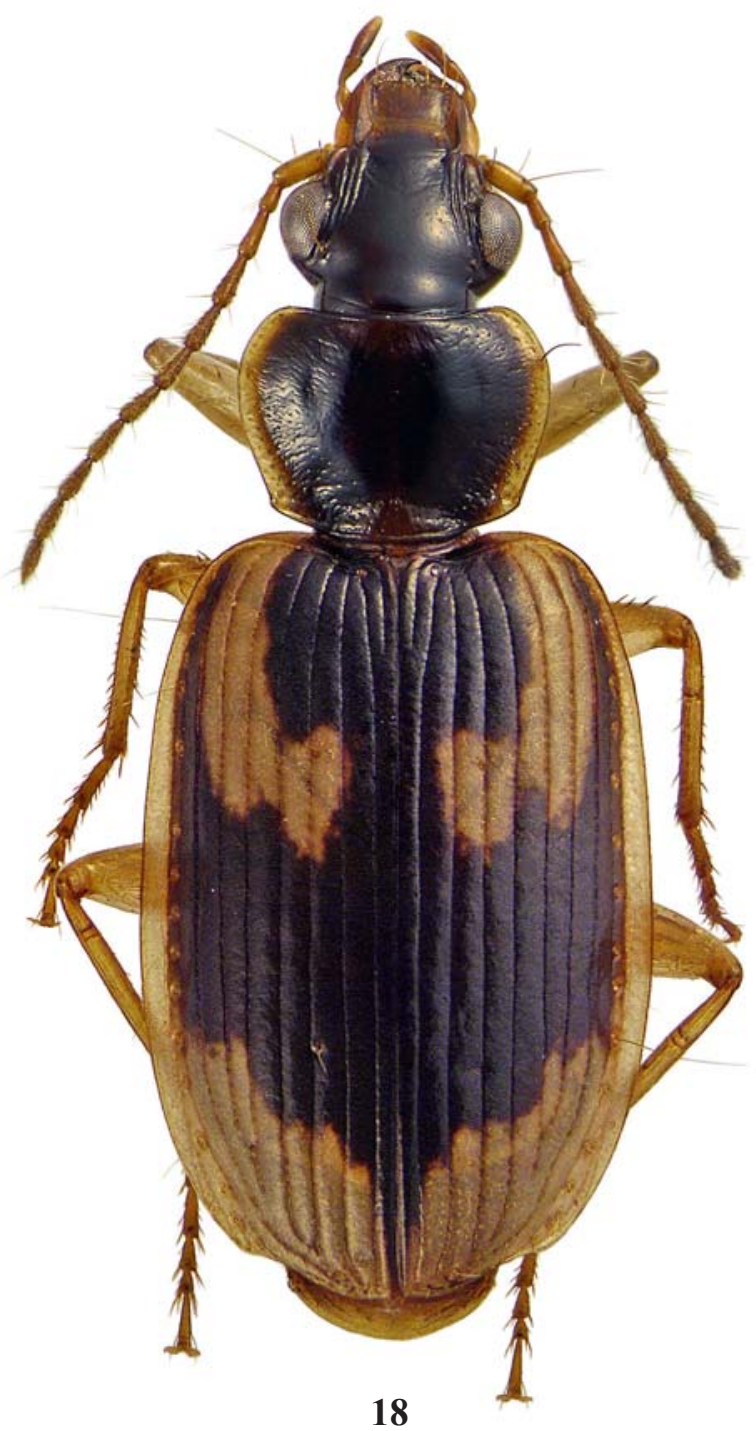

18

Рис. 17-18. Taridius, габитус сверху: $17-$ T. ornatus, экз. из Чуянгсина; $18-T$. marginipennis sp.n. 
Taridius ornatus Fedorenko, 2012

Fedorenko, 2012: 68 (Bi Doup Mt, S-Vietnam).

MATERIAL. $\sigma^{\top}, 4$ 우, Vietnam, Dak Lak Province, Chu Yang Sin Natn. Park, $12^{\circ} 23^{\prime} 48^{\prime \prime} \mathrm{N} / 108^{\circ} 21^{\prime} \mathrm{E}$, Krong Kmar river upper flow, h=1650 m, at light, 19.III-2.IV.2013 (D. Fedorenko); + , same data, but h=1650 m; O', 15-30.V.2014, h=970 m, at light; $\sigma^{7}, 2$, same data, but at light.

COMMENTS. Two new beetles are discussed below, both very similar to each other, as well as to T. ornatus with which they share nearly identical male and female genitalia.

The male genitalia are worthy of special mention. Firstly, the penile internal sac is rather simply structured in all examined species of Taridius. It looks like a poorly sclerotized and fairly long tube devoid of spines, sclerites or bulbs. Due to these traits, the folding pattern of the internal sac varies considerably between individuals of a particular species. On the other hand, these patterns have been found to be very similar in shape in some species. T. abdominalis Fedorenko, 2012 and T. ornatus are such and the internal sac as depicted by Fedorenko [2012: Figs 18 \& 24] for T. abdominalis should be considered as typical of both, whereas the illustrated internal sac of T. ornatus [ibid., Figs $20 \& 26$ ] as aberrant

Instead, interspecific differences are better seen from the comparison between apical lamellae of the penis. In profile, the lamella is short and tapering in T. abdominalis, but terminating in a subtle yet distinct rounded capitulum in $T$. ornatus. Another species, T. fasciatus Fedorenko, 2012 is highly similar to $T$. ornatus in the color pattern of the body, especially of the elytra, but well different in having the apical lamella nearly flat and gently upcurved at tip. Besides, central sclerotized patch of the penile internal sac is differently shaped in the latter two species, which stresses the differences between them.

The first of the new beetles mentioned above shows the following constant differences from typical $T$. ornatus: The body (Fig. 17) is smaller in general, BL 6.3-7.7 (vs. 7.4-8.4) $\mathrm{mm}$ in length. Elytral pale spots slightly larger (cf. Figs 21-22): subhumeral one outwardly extended to middle of interval 7 , more rarely reaching stria 8 (usually reaching stria 6 in $T$. ornatus); apical spot extends along lateral margin much farther forward than in T. ornatus, leaving medial dark fascia arrowhead rather than transverse and thence highly similar to that of $T$. fasciatus (Fig. 19) in shape. The number of frontal carinae on the head is about the same: four long carinae being mostly present each side, combined with a rudimentary, short and weak, inner carina. Observed in two local populations of T. ornatus (for details see 'MATERIAL' above), these differences seem to be rather slight and thence insufficient to erect a new subspecies.

DISTRIBUTION. This new insect is most likely to be an altitudinal form which substitutes for typical $T$. ornatus at lower altitudes. It is expected from this assumption to be more widespread than typical $T$. ornatus which probably covers one or several populations confined to higher mountain belts.

\section{Taridius marginipennis Fedorenko, sp.n.}

MATERIAL. Holotype $\sigma^{7}$ (ZMMU) and paratypes 4 우, $2 \sigma^{7} \sigma^{7}$ (SIEE) labelled: 'Vietnam, Lam Dong Prov[ince]., / 25 km NNW of Bao Loc, / Loc Bao env., h=800 m [asl], / Yang Sin Natn. Park, 11 ${ }^{\circ} 44^{\prime}$ $18^{\prime \prime} \mathrm{N} 107^{\circ} 42^{\prime} 08^{\prime \prime} \mathrm{E} /$ at light 5-20. / D. Fedorenko leg. IV.2013'.

DESCRIPTION. Body (Fig. 18) flat, 6.8-7.7 mm in length. Black or brown-black, anterior half of clypeus, labrum, mouthparts, antennae, metaventrite and prosternum along middle pale red; lateral margins of pronotum and legs, except for outer parts of metacoxae, reddish-yellow; pronotum reddish at base and apex. Last labial palpomere and last two maxillary palpomeres often very slightly infuscate. Elytra each with epipleuron, lateral margin, posthumeral longitudinal fascia and large apical spot yellow. Posthumeral fascia running on intervals 6 and 7 anteriorly, expanding onto 5 posteriorly and terminating a third from base; a small spot on intervals 3 and 4 slightly behind and fused to subhumeral fascia; apical spot large, its anterior margin much in front laterally than on intervals 2-3. Dark elytral pattern

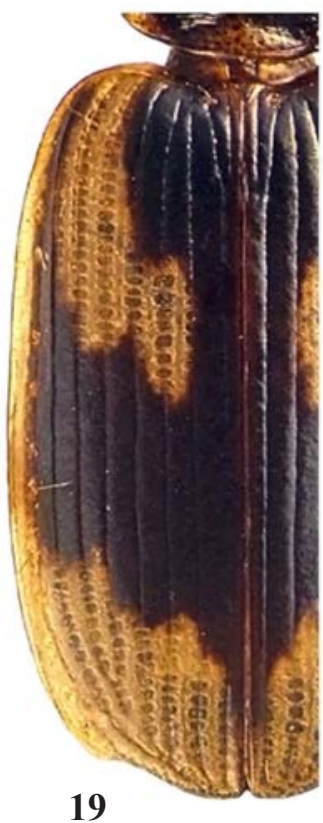

19

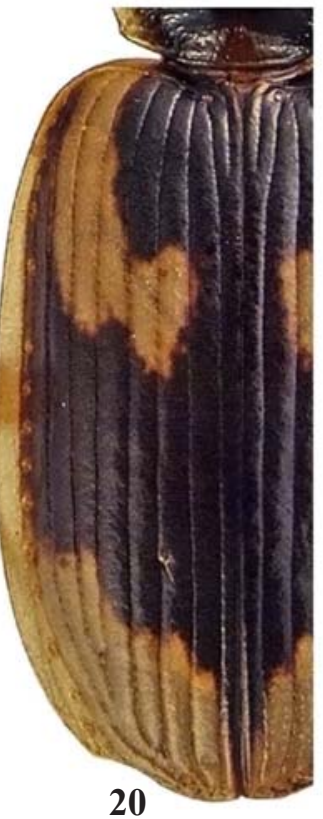

20
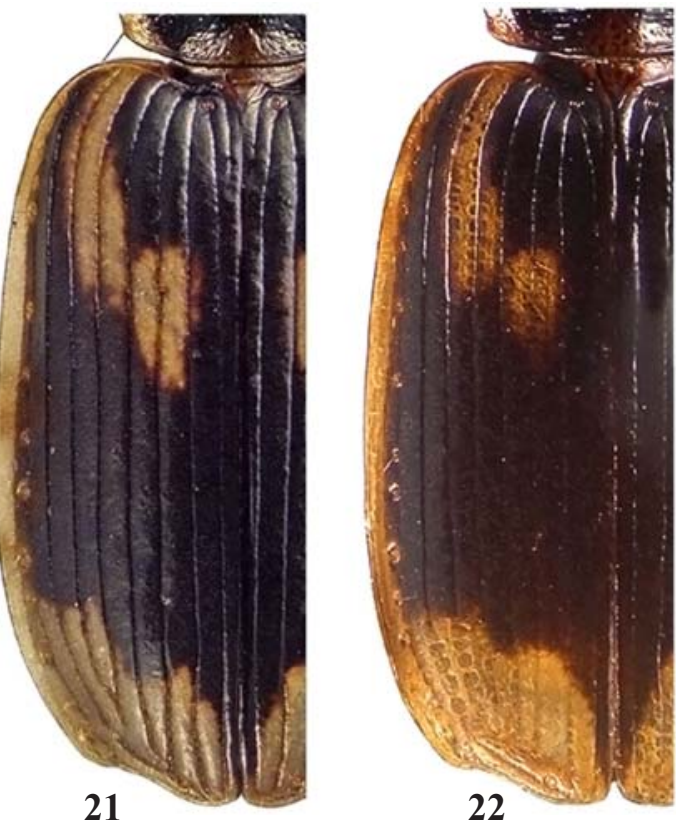

Figs 19-22. Taridius, left elytron: $19-$ T. fasciatus; $20-$ T. marginipennis sp.n.; 21 - T. ornatus from Chu Yang Sin; $22-$ T. ornatus from type locality.

Рис. 19-22. Taridius, левое надкрылье: $19-$ T. fasciatus; $20-$ T. marginipennis sp.n.; $21-$ T. ornatus из Чуянгсина; $22-$ T. ornatus из типовой местности. 
Table. Ratios of two species of Taridius.

Таблица. Проропорции тела двух видов Taridius.

\begin{tabular}{l|c|c|c|c|c}
\multicolumn{1}{c|}{ species, population } & $\mathbf{n}$ & $\mathbf{P W} / \mathbf{H W}$ & $\mathbf{P W} / \mathbf{P L}$ & $\mathbf{E W} / \mathbf{P W}$ & $\mathbf{E L / E W}$ \\
\hline ornatus, type loc. & 8 & $1.29-1.39(1.33)$ & $1.33-1.44(1.38)$ & $1.45-1.55(1.50)$ & $1.44-1.53(1.49)$ \\
ornatus, Chu Yang Sin & 5 & $1.31-1.35(1.32)$ & $1.36-1.44(1.41)$ & $1.49-1.58(1.55)$ & $1.47-1.51(1.49)$ \\
marginipennis & 7 & $1.25-1.31(1.29)$ & $1.35-1.44(1.41)$ & $1.57-1.70(1.65)$ & $1.43-1.49(1.46)$ \\
\hline
\end{tabular}

$\mathrm{n}$ - the number of specimens measured, means are given in round brackets;

$\mathrm{n}$ - количество измеренных экземпляров, средние значения приведены в скобках.

entire, with longitudinal sutural fascia running on intervals 1 and 2 while tapering to sutural angle posteriorly; medial fascia entire, very slightly shorter in interval 6 than in 5; submarginal strip on intervals 8 and 9 anteriorly while on 7 to 9 posteriorly.

Head and pronotum shining, without microsculpture or with its indistinct traces on frons and along sides of pronotum; elytra with sharp isodiametric microsculpture and thence somewhat dull. Head and pronotum sparsely and minutely punctate, elytra almost indistinctly so due to punctures very shallow. Body glabrous, metaventrite and abdomen moderately while prosternum less densely ciliate.

Head as in T. ornatus, but eyes slightly more convex and genae barely shorter. Neck constriction shallow yet traceable. Frontal carinae 3-4 each side, mostly three long carinae being present, often coupled with a rudimentary, slight and short, internal carina at the level of anterior supraorbital seta.

Pronotum transverse, subcordate, 1.35-1.44 (1.41, $\mathrm{n}=7)$ times as wide as long, $1.25-1.31(1.29, \mathrm{n}=7)$ times as wide as head, broadest a third from apex, with basal margin convex and strongly oblique laterally forwards, apex very gently concave. Sides rounded in apical half, straight behind. Apical angles rounded, basal ones highly obtuse, as small denticles due to a very gentle indentation of lateral margin just in front. Disc convex, median line fine and shallow, basal transverse impression invertedly $\mathrm{V}$-shaped, shallow medially, deep laterally; apical transverse impression very shallow to hardly traceable at middle only. Explanate lateral margin moderately reflexed and moderately wide, slightly wider at base while rather narrow just behind apical angle. Basal bead entire, apical bead obliterate at middle, lateral bead extremely narrow. Basal foveae shallow to indistinct. Disc a third from apex with a pair of small, slightly oblong, more or less shallow pits or impressions subequally distant from median line and lateral margin. Surface transversely rugulose, finely and sparsely on disc, much densely and conspicuously along sides including reflexed lateral margins; sides and base moderately densely and moderately coarsely punctate.

Elytra oblong-oval, 1.43-1.49 (1.46) times as long as wide, $1.57-1.70(1.65)$ times as wide as pronotum, broadest behind middle, each with preapical sinuation rather deep, posterolateral angle rounded yet distinct and apex truncate or very gently rounded. Striae well-impressed, slightly deeper basally and apically while shallower on disc behind middle, very finely crenulate throughout or only at base and at apex. Intervals flat, inner edge of interval 7 subcarinate in basal three fifths. Explanate lateral margin (interval 10) wide and reflexed in middle two fourths, clearly wider and more reflexed (especially so behind) than in the other congeners, nearly flat and extremely finely beaded along lateral edge.

Venter smooth. Last abdominal sternite bisetose in both sexes. Legs as for the genus.

Aedeagus and female stylomeres as described for T. ornatus, except for the details discussed in the section 'COMMENTS' to that species.

DIAGNOSIS. The new species strongly resembles $T$. ornatus in appearance, but the pronotum is clearly smaller and thence narrower relative to both the head and the elytra (Table). The elytra are more rounded at sides, their lateral margins clearly wider and more reflexed than in the other species, very gently concave at best and extremely finely beaded instead of narrow and moderately widely beaded. Besides, pale color on the elytra is more extensive due mainly to the posthumeral fasciae reaching stria 7 anteriorly and the lateral margins more widely pale following their great width. The elytral apices are nearly truncate (vs. rounded each, with a slight yet distinct reentrant angle in between); preapical sinuation barely deeper, posterolateral angles hardly more distinct. Three long frontal carinae mostly present on the head each side.

DISTRIBUTION. Known from type locality only.

NAME. Refers to the reflexed lateral margin of the elytrabeing wide and more widely pale than those of allied species of Taridius.

COMMENTS. T. marginipennis sp.n. and T. ornatus are currently known to be allopatric and very similar to each other. Given diagnostic features specified above, I consider them as quite separate species nevertheless, with reservation that they might be only subspecies of one species.

Sharing as they do a peculiar color pattern on the elytra (Figs 19-22), as well as quite similar proportions and microsculpture of the body, T. ornatus, $T$. marginipennis sp.n., $T$. fasciatus and $T$. vietnamensis are of highly similar facies. Only particular combination of such structural details as the number of the frontal carinae on the head, the body size, as well as the shape of the penis and its integrant parts, allows positive discrimination of these species.

ACKNOWLEDGEMENTS. I am very indebted to Dr. Gy. Szél (HNHM) and Dr. K.V. Makarov (MPSU) for the loan of material under their care. I also thank all my colleagues from the Russia-Vietnam Tropical Center who accompanied me during expeditions to Vietnam.

\section{References}

Andrewes H.E. 1923. Descriptions of some new Carabidae from Ceylon // Spolia Zeylanica. Vol.12. Pt.46. P.223-251.

Andrewes H.E. 1935. Keys to some Indian genera of Carabidae (Col.). V. The genera Cymindoidea, Platytarus, and Taridius // Stylops. Vol.4. No.9. P.201-205.

Andrewes H.E. 1940. Papers on Oriental Carabidae. - 36 // Ann. \& Mag. Nat. Hist. Ser.11. Vol.5. P.536.

Chaudoir M. 1875. Genres aberrants du groupe des Cymindides // Bull. de la Soc. Imp. Nat. Mosc. T.49. No.3. P.1-61.

Fedorenko D.N. 2010. New or little-known species of the genus Amphimenes Bates, 1873 (Coleoptera, Carabidae, Lebiinae) from Vietnam // ZooKeys. Vol. 65. P.14-50.

Fedorenko D.N. 2012. Notes on the genus Taridius Chaudoir, 1875 (Coleoptera, Carabidae, Lebiini), with descriptions of six new species from Vietnam // ZooKeys. Vol. 244. P. 67-89.

Habu A. 1964. On the species of the genus Amphimenes (Coleoptera, Carabidae) // Kontyû. Vol.32. No.4. P. 472-478.

Habu A. 1967. Carabidae Truncatipenne group (Insecta, Coleoptera). Fauna Japonica. Biogeographical Society of Japan. Tokyo. xiv $+338 \mathrm{pp} .+27 \mathrm{pl}$. 
Habu A. 1982. Revised and supplementary notes on and descriptions of the Truncatipennes group of Japan (II) (Coleoptera, Carabidae) // The entomological Review of Japan. Vol.37. No.2. P.83-118.

Jedlička A. 1963. Monographie der Truncatipennen aus Ostasien. Lebiinae - Odacanthinae - Brachininae (Coleoptera, Carabidae) // Entomol. Abh. Staatl. Mus. Dresden. Bd.28. Nr.7. S.269-579.

Kirschenhofer E. 1999. Über neue und wenig bekennte Carabiden Arten und Gattungen aus Südeurops, Kleiasien, Süd- und Südostasien (Coleoptera: Carabidae: Lebiinae) // Ann. Hist.-Nat. Mus. Natl. Hung. T.99. S.67-79.
Kirschenhofer E. 2003. Neue und wenig bekannte truncatipenne Carabidae aus Süd- und Südost Asien aus dem Ungarischen Naturwissenschaftlichen Museum Budapest (Coleoptera: Carabidae: Brachinini, Lebiini) // Ann. Hist.-nat. Mus. Natl. Hung. T.95. S.5-18.

Kirschenhofer E. 2010. New and little-known species of Carabidae from the Middle East and Southeast Asia (Coleoptera: Carabidae: Brachinini, Lebiini) // Ann. Hist.-nat. Mus. Natl. Hung. T.102. P.1-40. 